\title{
Meat quality of young Kamieniecka rams and Kamieniecka cross-breeds slaughtered at the age of 50 or 100 days
}

\author{
H. Brzostowski, Z. Tański, S. Milewski and Janina Sowińska
}

\author{
Institute of Breeding and Animal Production Technology, \\ Olsztyn University of Agriculture and Technology \\ lo-7I8 Olsztyn, Poland
}

(Received 17 January 1997; accepted 19 August 1997)

\begin{abstract}
The investigations were carried out on 48 ram-lambs: 16 Kamieniecka sheep $(\mathrm{K}), 16$ cross-breeds of Kamieniecka sheep ewes with Berrichon du Cher ( $\mathrm{K} \times \mathrm{BCH}$ ) and 16 with Blackhead (K x Blh) rams. Eight ram-lambs from each group were slaughtered at the age of 50 days and the remaining 8 animals at the agc of 100 days. Samples of the quadriceps muscle of the thigh (m. quadriceps femoris) were taken to investigate $\mathrm{pH}$, energy value, chemical, physical and sensory properties of the meat as well as fatty acid composition of the intramuscular fat.

The meat of $F_{1}$ cross-breeds after Berrichon du Cher rams had a higher fat content and better tenderness but worse water holding capacity and colour as well as less linolic acid $\left(\mathrm{C}_{1 \times 2}\right)$ in the intramuscular fat. Use of Blackhead rams resulted only in a darker colour of the meat as compared with that found in Kamieniecka sheep lambs.

The meat of 100 -day-old lambs had more protein and fat, higher energy value, better water holding capacity but worse tenderness, juiciness and taste. In comparison with results obtained from 50-day-old animals, the intramuscular fat of 100-day-old lambs contained more monounsaturated fatty acids, especially oleic acid $\left(\mathrm{C}_{18: 1}\right)$, but less saturated and unsaturated essential fatty acids.

Taste pancl evaluation as well as the fatty acid composition indicate that the meat from younger lambs is more suitable in terms of the human diet.
\end{abstract}

KEY WORDS: rams, cross-breeding, meat quality, $\mathrm{pH}$, fatty acid composition, sensory evaluation

\section{INTRODUCTION}

In economically developed countries, attention is paid not only to nutritional value but also to the wholesomeness of food products. Mutton obtained from 
lambs that are light (13-35 kg), well muscled, have little fat but high quality meat is in great demand on the markets of the European Union. This stems from consumer demand spurred by the desire to refrain from exceeding cholesterol consumption limits, thus the search for easily digestible meat with a low fat content, in which the existing fat is expected to have low melting and solidification points and a healthy fatty acid composition (Roborzyński et al., 1994; Prost, 1996).

The development of Polish sheep-farming largely depends on the export of lamb meat, hence intensifying investigations on not only how to increase meat production but also on how to improve its quality seems to be necessary. There is an opinion that cross-breeding of ewes of regional races, whose meat characteristics are not the best, with meat rams is a good way to improve meat quality (Kuchta and Lewczuk, 1983; Korzeniowski et al., 1986; Kędzior, 1991; Roborzyński et al., 1994; Tański et al., 1994; Brzostowski and Tański, 1995). Evaluation of meat quality of cross-breed lambs has usually focused on the chemical composition and some technological indices of meat. There are only few studies dealing with post-mortem glycolysis, energy value and fatty acid composition as indexes of lamb quality (Piestrak et al., 1977; Roborzyński, 1984; Wirth, 1986; Kędzior, 1991).

The aim of this study was to investigate the influence of cross-breeding of Kamieniecka ewes with Berrichon du Cher and Blackhead rams on meat quality indices in $F_{1}$ lambs slaughtered at the age of 50 and 100 days.

\section{MATERIAL AND METHOIS}

Investigations were carried out on 3 groups of ram-lambs: Kamieniecka $(\mathrm{K} ; \mathrm{n}=16)$ and cross-breeds of Kamieniecka ewes with Berrichon du Cher $(\mathrm{K} \times \mathrm{BCH} ; \mathrm{n}=16)$ and Blackhead $(\mathrm{K} \times \mathrm{Blh} ; \mathrm{n}=16)$ rams.

All lambs were traditionally fed hay, mangolds and concentrate mixture for calves and lambs C-J (consisting of, \%: crushed wheat 40, middlings 24 and protein concentrate also containing minerals, vitamins and growth stimulators, 36, according to Polish standards (Feeding Standards, Institute of Animal Production, 1985) for suckling lambs.

Eight randomly selected young rams from each group were killed at the age of 50 days, and the remaining 8 animals at the age of 100 days. The weight of 50 -day-old lambs before killing was: $\mathrm{K}-16.86 \mathrm{~kg}$; $\mathrm{K} \times \mathrm{BCH}-17.62 \mathrm{~kg}$; $\mathrm{K} \times \mathrm{Blh}-18.02 \mathrm{~kg}$; and of 100-day-old animals: $29.51,30.52,31.33 \mathrm{~kg}$, respectively. Samples of the quadriceps muscle of the thigh $(m$. quadriceps femoris) were taken to evaluate the quality of the meat and intramuscular fat. In the collected samples, the following indices were determined: dry matter by 
drying the tissues at $105^{\circ} \mathrm{C}$, protein using Kjeldahl's method, crude ether extract using the Soxhlet method, crude ash ofter furnacing at $550^{\circ} \mathrm{C}$, gross energy using an adiabatic calorimeter KL-10 bomb, water holding capacity by using the Grau and Hamm methods (1953), colour intensity using a Specol spectrocolorimeter with remission device $\mathrm{R} 045$ at a wavelength of $560 \mathrm{~mm}, \mathrm{pH}$ after 10 and $90 \mathrm{~min}$ and after $6,12,18,24$ and $48 \mathrm{~h}$ following the slaughter using a PHM $22 \mathrm{pH}$-meter.

Thermal processing for sensory evaluation was performed according to Baryłko-Pikielna (1975). A five point scale was used to describe following quality indices: aroma and taste (intensity and desirability) as well as tenderness and juiciness. The fatty acid composition of the intramuscular fat was estimated by the esterification method (Peisker, 1964) followed by gas chromatography according to Żegarska et al. (1979).

The results were statistically evaluated using variance analysis in a binary orthogonal system.

\section{RESULTS AND DISCUSSION}

The chemical composition and physico-chemical characteristics of meat (Table 1) revealed that the rams of meat breeds used for cross-breeding with the Kamieniecka sheep ewes exerted a pronounced influence on some indexes in $F_{1}$ lambs.

Meat of the lambs from Berrichon du Cher rams contained significantly more $(\mathrm{P} \leqslant 0.05)$ fat $(1.63 \%)$ than meat from the Kamieniecka sheep lambs $(1.30 \%)$. The results obtained by Kuchta and Lewczuk (1983), Korzeniowski et al. (1986) and Kędzior (1991) have also showed that differences in the fat content of the meat depend on the race of rams used for cross-breeding. The higher content of fat in the meat of cross-breeds $\mathrm{K} \times \mathrm{BCH}$ slightly increased its energy value. The energy value determined in the meat of lambs, $\mathrm{K}-127.96, \mathrm{~K} \times \mathrm{BCH}-130.11$ and $\mathrm{K} \times \mathrm{Blh}-128.50 \mathrm{kcal} / 100 \mathrm{~g}$, should be considered relatively low, thus, conforming to the principles of modern nutrition that recommend lower amounts of energy in larger quantities of food (Prost, 1996). As compared to $\mathrm{K}$ lambs, the higher fat and lower protein contents in the meat of $\mathrm{K} \times \mathrm{BCH}$ lambs resulted in its poorer water holding capacity. The significant differences in the colour of the meat between the studied groups of the lambs were probably breed-dependent.

The age of the slaughtered lambs highly influenced the chemical composition and physico-chemical characteristics of the meat. The meat of 100 -day-old lambs contained more dry matter than the meat of 50-day-old rams (Table 1), resulting in a higher energy value of the meat $(\mathrm{P}<0.01)$. Covington et al. $(1970)$ have suggested that the increase in fat and the decrease in water content of the meat 
TABLE 1

Chemical composition, water holding capacity and colour of meat

\begin{tabular}{|c|c|c|c|c|c|c|}
\hline \multirow{2}{*}{ Specification } & & \multicolumn{3}{|c|}{ Groups } & \multicolumn{2}{|c|}{ Age, days } \\
\hline & & K & $\mathrm{K} \times \mathrm{BCH}$ & $\mathrm{K} \times \mathrm{Blh}$ & 50 & 100 \\
\hline \multirow[t]{2}{*}{ Dry matter, \% } & mean & 23.04 & 23.02 & 23.16 & $22.49^{\mathrm{B}}$ & $23.66^{\wedge}$ \\
\hline & S.D. & 1.02 & 1.04 & 1.25 & 0.96 & 0.88 \\
\hline \multirow[t]{2}{*}{ Crude protein, $\%$} & mean & 19.41 & 19.28 & 19.45 & $19.14^{b}$ & $19.62^{\mathrm{a}}$ \\
\hline & S.D. & 0.84 & 0.72 & 0.79 & 0.78 & 0.69 \\
\hline \multirow[t]{2}{*}{ Fat, \% } & mean & $1.30^{\mathrm{b}}$ & $1.63^{\mathrm{a}}$ & 1.52 & $1.30^{\mathrm{B}}$ & $1.67^{\mathrm{A}}$ \\
\hline & S.D. & 0.35 & 0.39 & 0.45 & 0.41 & 0.33 \\
\hline \multirow[t]{2}{*}{ Ash, $\%$} & mean & 1.17 & 1.19 & 1.16 & 1.17 & 1.18 \\
\hline & S.D. & 0.05 & 0.06 & 0.05 & 0.06 & 0.05 \\
\hline \multirow[t]{2}{*}{ Kcal } & $\mathrm{GE} / 100 \mathrm{~g}$ mean & 127.96 & 130.11 & 128.50 & $124.94^{\mathrm{B}}$ & $132.78^{\mathrm{A}}$ \\
\hline & S.D. & 8.18 & 10.54 & 9.14 & 7.86 & 8.86 \\
\hline \multirow[t]{2}{*}{ Water holding capacity, $\mathrm{cm}^{2}$} & mean & $6.90^{\mathrm{b}}$ & $8.13^{\mathrm{a}}$ & 7.54 & $7.93^{\mathrm{a}}$ & $7.11^{\mathrm{b}}$ \\
\hline & S.D. & 1.49 & 1.55 & 1.21 & 1.29 & 1.58 \\
\hline \multirow[t]{2}{*}{ Colour, $\%$} & mean & $16.81^{\mathrm{A}}$ & $14.8 \mathrm{I}^{\mathrm{B}}$ & $14.56^{B}$ & $17.08^{\wedge}$ & $13.71^{\mathrm{b}}$ \\
\hline & S.D. & 2.71 & 2.90 & 2.42 & 2.67 & 1.78 \\
\hline
\end{tabular}

$\mathrm{a}, \mathrm{b}-\mathrm{P}<0.05 ; \mathrm{A}, \mathrm{B}-\mathrm{P}<0.01$

promote its higher physiological maturity. The ratio of water to fat in the meat of 100 -day-old and 50-day-old rams (46.22 and 59.62, respectively) indicates that the meat of older animals is more mature, which confirms this opinion. The older age of the animals improved the water holding capacity $(\mathrm{P}<0.05)$ of the meat but its colour was worse $(\mathrm{P}<0.01)$, probably because of the higher myoglobin content resulting from more intense muscle function in the older animals.

The changes in the $\mathrm{pH}$ of meat (Table 2) reflect the intensity of post-mortem glycolysis, and thus, the meat quality. $\mathrm{pH}$ values of the meat of $\mathrm{K}-6.83$, $\mathrm{K} \times \mathrm{BCH}-6.76$ and $\mathrm{K} \times \mathrm{Blh}-6.96$ rams measured 10 min after slaughter indicate that the animals were properly prepared for slaughter. The results obtained in the present study are in agreement with those found by Piestrak et al. (1977) and Roborzyński (1984). The relatively slow decrease in the $\mathrm{pH}$ value after slaughter in our investigations suggests that glycolysis proceeded normally. The $\mathrm{pH}$ value of the meat stabilized at 5.51-5.56 no earlier than $24 \mathrm{~h}$ after slaughter because this period was needed for glycogen to be converted into lactic acid. According to Wirth (1986), very fast glycolysis that causes a decrease in $\mathrm{pH}$ to below 5.8 occurs in meat with PSE (pale, soft, exudative) syndrome, and shortened glycolysis or 
TABLE 2

Changes of $\mathrm{pH}$ values of lambs meat after slaughter

\begin{tabular}{|c|c|c|c|c|c|c|c|c|c|}
\hline \multirow{2}{*}{\multicolumn{3}{|c|}{ Time after slaughter }} & & 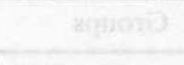 & \multicolumn{3}{|c|}{ Groups } & \multicolumn{2}{|c|}{ Age, days } \\
\hline & & & & diti $\mathrm{x} \times \mathrm{x}$ & $\mathrm{K}$ & $\mathrm{K} \times \mathrm{BCH}$ & $\mathrm{K} \times \mathrm{Blh}$ & 50 & 100 \\
\hline \multirow[t]{2}{*}{$10 \mathrm{~min}$} & t6:-64t & 19.8 & & mean & 6.83 & 6.76 & 6.96 & 6.87 & 6.85 \\
\hline & & & & S.D. & 0.28 & 0.27 & 0.23 & 0.28 & 0.26 \\
\hline \multirow[t]{2}{*}{$90 \mathrm{~min}$} & & 480 & & mean & $6.51^{\mathrm{B}}$ & $6.50^{\mathrm{B}}$ & $6.82^{\mathrm{A}}$ & 6.54 & 6.68 \\
\hline & & & & S.D. & 0.30 & 0.27 & 0.37 & 0.29 & 0.38 \\
\hline \multirow[t]{2}{*}{$6 \mathrm{~h}$} & & cat if & & mean & 6.26 & 6.28 & 6.21 & $6.33^{\mathrm{a}}$ & $6.17^{b}$ \\
\hline & & & & S.D. & 0.31 & 0.26 & 0.30 & 0.26 & 0.28 \\
\hline \multirow[t]{2}{*}{$12 \mathrm{~h}$} & & abeit & Pfet & mean & 6.24 & 6.01 & 6.19 & 6.32 & 5.98 \\
\hline & teasese & & thestert & S.D. & 0.32 & 0.29 & 0.34 & 0.31 & 0.24 \\
\hline \multirow[t]{2}{*}{$18 \mathrm{~h}$} & & & & mean & $6.18^{\mathrm{a}}$ & $5.91^{\mathrm{b}}$ & 6.02 & $6.24^{A}$ & $5.83^{\mathrm{B}}$ \\
\hline & & & & S.D. & 0.40 & 0.39 & 0.63 & 0.43 & 0.45 \\
\hline \multirow[t]{2}{*}{$24 \mathrm{~h}$} & & & & mean & 5.51 & 5.56 & 5.53 & 5.54 & 5.53 \\
\hline & & & & S.D. & 0.07 & 0.09 & 0.05 & 0.08 & 0.07 \\
\hline \multirow[t]{2}{*}{$48 \mathrm{~h}$} & & & & mean & 5.51 & 5.56 & 5.53 & 5.54 & 5.53 \\
\hline & $x^{2}$ & & whese & S.D. & 0.07 & 0.09 & 0.05 & 0.08 & 0.07 \\
\hline
\end{tabular}

$\mathrm{a}, \mathrm{b}-\mathrm{P}<0.05 ; \mathrm{A}, \mathrm{B}-\mathrm{P}<0.01$

even no glycolysis is found in the meat with DFD (dark, firm, dry) syndrome, where $\mathrm{pH}$ usually does not decrease below 6.2. According to Schieffer and Scharners (1977) scale of the final $\mathrm{pH}$ values obtained in the present study fits the optimal values (5.5-5.9) characteristic of high quality meat. The significant differences in the rate of $\mathrm{pH}$ decrease at $90 \mathrm{~min}$ and $18 \mathrm{~h}$ after slaughter, observed among the particular ram groups, are probably breed-dependent because the rearing, transportation and slaughter of the animals were the same in each group. Post-mortem glycolysis was less disarrayed in the older lambs which were more resistant to stress. This resulted in significant age-dependent differences in the $\mathrm{pH}$ values measured 6,12 and $18 \mathrm{~h}$ after slaughter between the groups.

Analysis of the fatty acid composition of intramuscular fat (Table 3) revealed the presence of 16 acids with 12 to $20 \mathrm{C}$ in the molecule. $\mathrm{C}_{18: 1}(39.1-39.7 \%), \mathrm{C}_{16: 0}$ $(23.9-24.6 \%)$ and $\mathrm{C}_{18: 0}(14.8-15.2)$ acids were prevalent, independent of the breed of the animals. Breed has been found to influence the level of only $\mathrm{C}_{18: 2}$ acid. In $\mathrm{K} \times \mathrm{BCH}$ rams, and a less advantageous, from the physiological point of view, amount of this acid was noted $(\mathrm{P}<0.05)$. This caused an increase in the total amount of saturated fatty acids in 3.6 and $3.2 \%$ as compared with results 
TABLE 3

Fatty acid composition of intramuscular lipids, \%

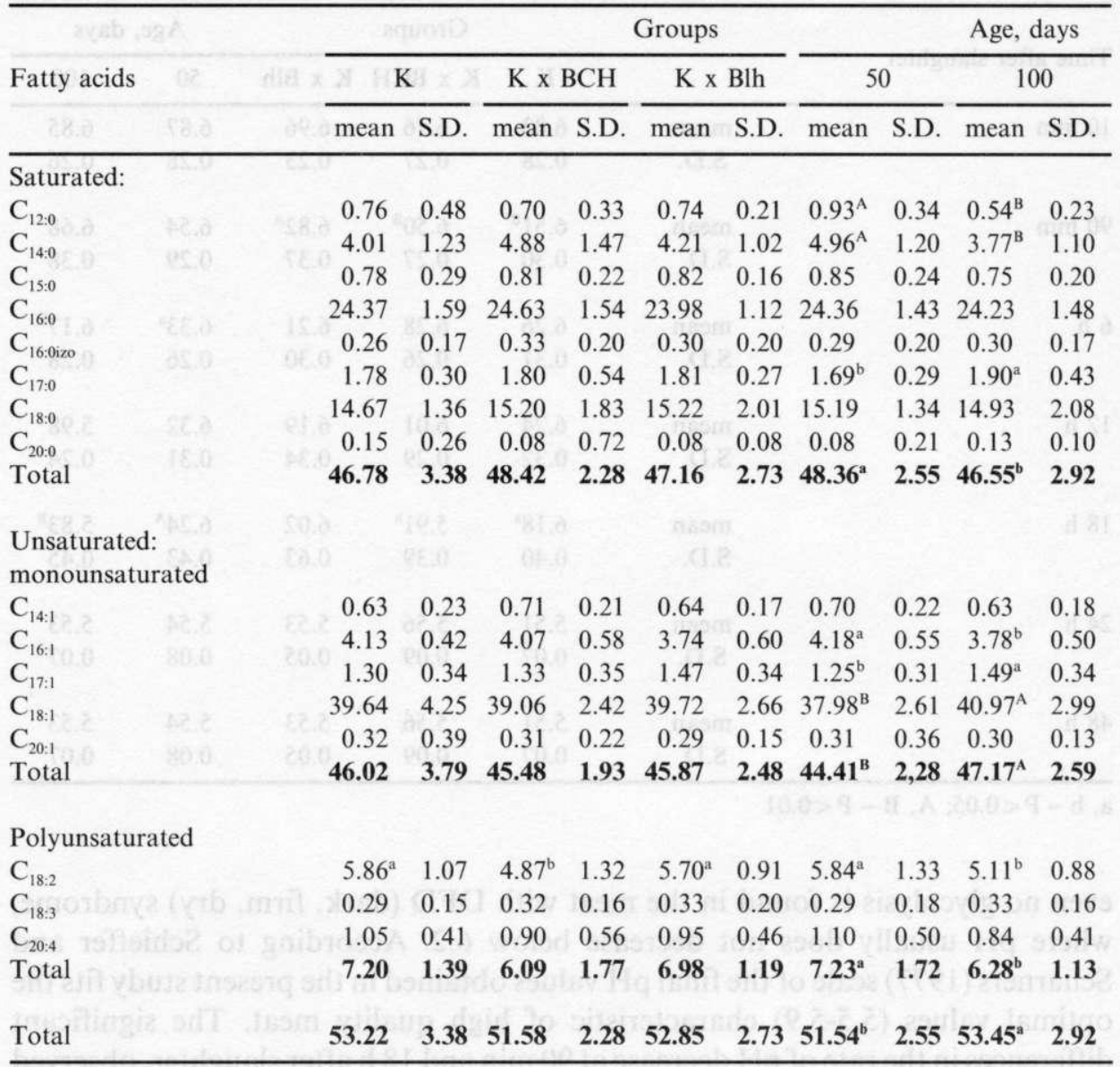

$\mathrm{a}, \mathrm{b}-\mathrm{P}<0.05 ; \mathrm{A}, \mathrm{B}-\mathrm{P}<0.01$

obtained in K-and to K x Blh rams, respectively. Boylan et al. (1976), Ch'ang et al. (1980) and Kędziora (1991) have found that breed has an even greater influence on meat fatty acid composition, but they used older sheep in their investigations.

Fatty acid composition was significantly influenced by the age of animals. In the intramuscular fat of 100-day old rams the proportion of saturated fatty acids was lower than unsaturated ones $(\mathrm{P}<0.05)$ in comparison with 50 -day-old animals. In the group of unsaturated fatty acids, in 100-day-old lambs a significant decrease in the amount of polyunsaturated acids, but a significant increase in monounsaturated, especially $\mathrm{C}_{18: 1}$, acids was observed. The results 
TABLE 4

Sensory evaluation of meat, score

\begin{tabular}{|c|c|c|c|c|c|c|}
\hline \multirow{2}{*}{ Specification } & & \multicolumn{3}{|c|}{ Groups } & \multicolumn{2}{|c|}{ Age, days } \\
\hline & & $\mathrm{K}$ & $\mathrm{K} \times \mathrm{BCH}$ & $\mathrm{K} \times \mathrm{Blh}$ & 50 & 100 \\
\hline \multirow[t]{2}{*}{ Tenderness } & mean & $4.42^{B}$ & $4.68^{\mathrm{a}}$ & 4.53 & $4.71^{4}$ & $4.38^{\mathrm{b}}$ \\
\hline & S.D. & 0.54 & 0.47 & 0.50 & 0.46 & 0.49 \\
\hline \multirow[t]{2}{*}{ Juiciness } & mean & 4.54 & 4.74 & 4.56 & $4.77^{\mathrm{a}}$ & $4.46^{b}$ \\
\hline & S.D. & 0.49 & 0.44 & 0.44 & 0.39 & 0.46 \\
\hline \multirow[t]{2}{*}{ Aroma - intensity } & mean & 4.88 & 4.88 & 4.81 & 4.92 & 4.79 \\
\hline & S.D. & 0.29 & 0.29 & 0.31 & 0.19 & 0.36 \\
\hline \multirow{2}{*}{ Aroma - desirability } & mean & 4.88 & 4.88 & 4.91 & 4.92 & 4.85 \\
\hline & S.D. & 0.22 & 0.29 & 0.20 & 0.19 & 0.28 \\
\hline \multirow[t]{2}{*}{ Taste - intensity } & mean & 4.47 & 4.66 & 4.56 & 4.67 & 4.46 \\
\hline & S.D. & 0.50 & 0.44 & 0.48 & 0.46 & 0.46 \\
\hline \multirow[t]{2}{*}{ Taste - desirability } & mean & 4.66 & 4.72 & 4.59 & $4.77^{u}$ & $4.54^{\mathrm{h}}$ \\
\hline & S.D. & 0.44 & 0.41 & 0.42 & 0.39 & 0.41 \\
\hline \multirow[t]{2}{*}{ General evaluation } & mean & 4.64 & 4.76 & 4.67 & $4.80^{\mathrm{a}}$ & $4.58^{\mathrm{h}}$ \\
\hline & S.D. & 0.45 & 0.38 & 0.40 & 0.36 & 0.44 \\
\hline
\end{tabular}

$\mathrm{a}, \mathrm{b}-\mathrm{P}<0.05$

obtained by Tański et al. (1994) also suggest an age-dependent difference in fatty acid composition. This study has shown that the level of palmitic acid, the main determinant of the blood cholesterol level, was similar in the particular age groups, but the amount of unsaturated essential fatty acids in the fat of 50-day-old rams was significantly higher, which suggests that for humans, meat from younger lambs is preferable.

Analysis of the test panel evaluation (Table 4) points to the high quality of meat regardless of the breed of the rams used for cross-breeding or the age of the slaughtered lambs. The mean score value was from 4.42 - to 4.91 points within the particular breed group. The slightly higher score for tenderness, juiciness and taste intensity in case of the meat of $\mathrm{K} \times \mathrm{BCH}$ lambs was probably due to its higher fat content, which gave a looser connective tissue ultrastructure. Smith and Carpenter (1970) have found that the presence of intramuscular fat positively influences the above meat characteristics. The worsening of the tenderness, juiciness and taste of the meat from 100-day-old lambs was probably a result of the larger diameter of its muscle fibres and a more compact structure of the connective tissue which was meaningfully darker as compared to the characteristics of the meat from 50-day-old animals. 


\section{CONCLUSIONS}

Cross-breeding of Berrichon du Cher rams with Kamieniecka ewes produces an increase in fat content, better tenderness, worsens the water holding capacity and colour as well as causes an unfavourable decrease in the linolic acid $\mathrm{C}_{18: 2}$ content in the intramuscular fat of the meat from $F_{1}$ lambs. Using Blackhead rams results only in a darker colour of the meat from the lambs.

An increase in the protein and fat content as well as in the energy value and water holding capacity, but the worsening of tenderness, juiciness, taste and the colour of the meat of lambs with age is observed.

In the intramuscular fat of 100-day old rams the proportion of monounsaturated, especially $\mathrm{C}_{18: \mathrm{l}}$, fatty acids is higher, but that of saturated and unsaturated essential fatty acids is lower.

The physical and sensory characteristics as well as the fatty acid composition indicate that as far as the human diet is concerned, meat from younger lambs is more suitable.

\section{REFERENCES}

Baryłko-Pikielna N., 1975. The draft of the ood sensory analysis (in Polish). WNT, Warszawa Boylan W.J., Berger Y.M., Allen C.E., 1976. Fatty acid composition of Finnsheep crossbreed lamb carcasses. J. Anim. Sci. 42, 1421-1426

Brzostowski H., Tański Z., 1995. Some quality indices of frozen meat of Kamieniecka and Blackhead young rams, and their crossbreds (in Polish). Zesz. nauk. PTZ, Workshop in ultrasonography - A new approach at improving meat quality of sheep. No 22, 29-37

Ch'ang T.S.. Evans R., Hood R.L., 1980. Sire effect on fatty acid composition of ovine adipose tissue. J. Anim. Sci. 31, 697-706

Covington R.C., Tuma H.J., Grant D.L., Dayton A.D., 1970. Various chemical and histological characteristics of beef muscle as related to tenderness. J. Anim. Sci. 30, 191-196

Grau R.. Hamm R., 1953. Über das Wasserbindung vermögen des toten Saugeticrmuskels. I. Mitteilung. Der Einfluss des $\mathrm{pH}-$ Wertes auf die Wasserbindung von der zerkleinertem. Rinder Muskel Biochem. 1, 325-328

Kedzior W., 1991. Influence of the commercial cross-breeding of the submountain sheep on the quality of the meat of lambs (in Polish). Rocz. Inst. Przem. Mięsn. Tłuszcz. 28, 121-131

Kędzior W.. 1991. Influence of the cross-breeding on the composition of fatty acids in the fat of lambs (in Polish). Rocz. Inst. Przem. Mięsn. Tłuszcz. 28, 136-147

Korzeniowski W., Bojarska U.. Ostoja H., 1986. The chemical composition and some technological properities of meat lambs of Polish Long-wool and Lowland sheep and their crossbreds with meat breed sires (in Polish). Rocz. Nauk rol. B-103, $77-89$

Kuchta G., Lewczuk A., 1983. Effect of sirc-breed, sex and birth type on meat quality of Pomorian sheep (in Polish). Zesz. nauk. ART Olszlyn 25, 65-73

Peisker K.V., 1964. A rapid semi-micro method for prepartion of methyl esters from triglycerides using chloroform, methanol, sulphuric acid. J. Amer. Oil Chem. Sci. 41, 87-88

Piestrak T., Kołczak T., Brzozowska M., 1977. Some properties of meat from lambs of the Polish Mountain bred and crosses of the Polish Mountain sheep with Ile de France rams and the 
Long-wool Polish sheep (Rząskowiska variety) (in Polish). Rocz. Inst. Przem. Mięsn. Tluszcz.14, 41-46

Prost E., 1996. Food of animal origin - its wolesomeness and metrition value (in Polish). Proccedings of International Symposium "Slaughter value and meat quality of farm animals in relation to genetic and environmental conditions", Lublin (Poland), pp. 39-53

Roborzyński M.. 1984. Lamb-meat performance in crossbreds $F_{1}$ obtained from Polish Mountain ewes and rams of other breeds (in Polish). Acta Agr. Silv., Scr. Zoot. 23, 53-65

Roborzyński M., Skrzyżala J., Kieć W., Knapik J., 1994. Fattening ability and slaughter value of Pogórza sheep lambs and crosses with meat-type rams (in Polish). Zesz. nauk. PTZ, Sheep breeding, No 13, 227-234

Schieffer G., Scharner E., 1977. Einflus von Alter, Lebendmasse, Geschlecht und Geburtstyp auf ausgewahlte Qualitätsparameter von Mastlammfleisch. Arch. Tierzucht. 20, 129-136

Smith G.C., Carpenter Z.L., 1970. Lamb carcass quality. III. Chemical, physical and histological measurement. J. Anim. Sci, 31, 697-706

Tański Z., Brzostowski H., Milewski S., Stempel R., 1994. The influence of the slaughter age of ram lambs of the Polish Merino breed and crossbreds on somc meat quality indices (in Polish). Zesz.. nauk. PTZ, Sheep breeding. No 13, 251-258

Wirth F., 1986. The technology of processing meat not of standard quality. Fleischwirtschaft 66 , $1256-1260$

Żegarska Z., Markicwicz K., Smoczyński S., 1979. Composition of fatty acids in muscule fat and depot fat of rabbits (in Polish). Zesz. Nauk. ART Olsztyn 15, 167-177

\section{STRESZCZENIE}

\section{Jakość mięsa tryczków owcy kamienieckiej i jej mieszańców ubijanych w wieku 50 i 100 dni}

Badania przeprowadzono na 48 tryczkach: 16. owcy kamienieckiej (K), 16. mieszanicach po trykach Berrichon du Cher $(\mathrm{K} \times \mathrm{BCH})$ i 16. mieszańcach po trykach czarnogłówki $(\mathrm{K} \times \mathrm{Blh})$. W 50 i 100 dniu życia $z$ każdej grupy rasowej ubito po 8 zwierząt. W miçśniu cztcrogłowym uda (m. quadriceps femoris) oznaczono: pl I, skład chemiczny, właściwości firyczne i sensoryczne, wartość energetyczną i skład kwasów tłuszczowych tłuszczu śródmięśniowego.

U micszańców $F_{1}$ po trykach Berrichon du Cher większa była zawartość tłuszczu w mięsie, lepsza kruchość, gorsza wodochlonność i barwa miçsa oraz mniejszy udział kwasu linolowego $\left(\mathrm{C}_{1 \mathrm{k}: 2}\right)$ w tłuszczu śródmięśniowym mięsa, po trykach czarnogłówki jedynie barwa mięsa była ciemniejsza niż u jagniąt owcy kamienieckiej.

W mięsie jagniąt 100-dniowych większa była zawartość białka i tluszczu oraz wartość energetyczna, a takł̇e wodochłonność, gorsza natomiast kruchość, soczystość i smak mięsa. W tłuszczu śródmięśniowym mięsa większy był proccntowy udział kwasów jednonienasyconych, głównic oleinowego $\left(\mathrm{C}_{18.1}\right)$, ale mniejszy nasyconych $\mathrm{i}$ niezbędnych nienasyconych kwasów tłuszc7.owych niż u jagniąt 50-dniowych.

Właściwości fizyczne i sensoryczne mięsa oraz proporcje w stopniu nasycenia kwasów tłuszczowych wskazują, że z punktu widzenia potrzeb człowicka lepsze jakościowo jest mięso 50-cio niż 100-dniowych jagniąt. 